\title{
The Vermont Connection
}

Volume 35 (Re)creating New Domains: The Future of Higher Education

January 2014

\section{Black Identity Development}

Keyiona Ritchey

Follow this and additional works at: https://scholarworks.uvm.edu/tvc

Part of the Higher Education Administration Commons

\section{Recommended Citation}

Ritchey, K. (2014). Black Identity Development. The Vermont Connection, 35(1).

https://scholarworks.uvm.edu/tvc/vol35/iss1/12

This Article is brought to you for free and open access by the College of Education and Social Services at UVM ScholarWorks. It has been accepted for inclusion in The Vermont Connection by an authorized editor of UVM ScholarWorks. For more information, please contact scholarworks@uvm.edu. 


\title{
Black Identity Development
}

\author{
Keyiona Ritchey
}

\begin{abstract}
The purpose of this literature review is to discuss the stages of Black identity development among Black students in higher education attending predominantly White institutions (PWIs). I explore the different stages of Nigrescence, which is the process of becoming Black (Cross, 1991). Research on Black identity development is critical for student affairs professionals because it can serve as a foundation to help understand different developmental processes that Black students may experience in college. Ultimately, competency in Nigrescence can belp influence bow student affairs professionals belp support Black. students as they learn to navigate their racial identity in college. Additionally, student affairs professionals can help aid in persistence and retention efforts made by colleges.
\end{abstract}

\section{Higher Education}

Student affairs professionals should understand the different dynamics of Black identity development and the ways it might play out on college campuses when working with students from diverse backgrounds. Identity conflict is largely responsible for a significant number of early departures from a college campus (Harper \& Quaye, 2007). It is important to keep in mind that every student is at different stages in their developmental process. Support might look different for every student. Institutions of higher education have come a long way in terms of multicultural competency. Nonetheless, there is still progress to be made. I will explore Black identity development among Black students attending predominantly White institutions (PWIs) and the implications for student affairs professionals. I use Black identity development and Nigrescence interchangeably.

Applying to and being accepted to college is something many American youth excitedly anticipate. Transitioning to college is a significant life change for young

Keyiona Ritchey is a 2nd year HESA student. She is the graduate assistant for study abroad in the Office of International Education. She received her B.A. from California State University Dominguez. Hills with a major in Human Services and a minor in Africana Studies. Her passions are in racial identity development, education abroad, and helping students with non-dominant identities navigate bigher education. 
adults. It is typically the first time young adults are living away from home and gaining a sense of independence. Magolda (2001) expressed that "higher education has a responsibility to help young adults make the transition from their socialization by society to their role as members and leaders in society's future" (p. 25). College is a place where young adults learn how to positively contribute to society. Since higher education is tasked with socializing young adults to be productive members of society, this transformation looks different for each student based on their racial identity. Therefore, it is critical for student affairs professionals to understand the different dynamics of Black identity development.

Racism significantly impacts racial identity development in the United States. Adams (2005) stated that

Race is the sharpest and deepest division in American life, and because of the long standing divide, achieving equal access to and benefits from institutions of higher education has been an ongoing struggle for people of color in general, but particularly for African Americans. (p. 285)

College is where young adults begin to question their identity and explore the question of "who am I?" (Magolda, 2001, p. 4). Black students attending PWIs can face racism, isolation, sociocultural challenges, and academic obstacles (Harper \& Quaye, 2007). In addition, Black students become aware of the implications of what it means to be Black during college among their White peers. For Black students attending college, Bakari (1997) stated that "a positive racial identity helps create a positive attitude and confidence in one's ability, therefore, a positive racial identity is critical for the academic success and personal development of African American students" (p. 1). Therefore, it is critical for student affairs professionals to be knowledgeable in Black identity development since a positive racial identity is linked to academic and personal success. This ultimately contributes to Black students graduating and being productive members of society.

\section{Why Are All The Black Kids Sitting Together?}

When Black students do not fit into the mainstream culture they tend to group with other people who look like them for support. Tatum (1997) said that

joining with one's peers for support in the face of stress is a positive coping strategy. What is problematic is that the young people are operating with very limited definitions of what it means to be Black, based largely on cultural stereotypes. (p. 62)

Black students "sit at the same table" (p. 62) because it is comfortable for them. They face challenges in a setting where they stand out and "academic success is often associated with being White" (p. 62). Tatum (1997) acknowledged that students seek support from what is comfortable to them. As a result "Black students turn to each other for the much needed support they are not likely to find anywhere" (p. 60) in order to persevere and graduate. 
Bakari (1997) argued that PWIs often fail to meet the challenges of cross cultural student development for Black students. They continue to operate under the melting pot theory, where everyone is expected to fit into the mainstream White middle class value structure. This creates barriers and a climate that is not conducive for students whose identities fall outside of being White and middle class. Reflecting on her experiences as a student bell hooks (1994) recounted "I know from personal experience as a [Black woman] student in a predominantly white institution how easy it is to feel shut out or closed down" (p. 86).

Negative stereotypes about Black culture are imposed upon Black students. Stereotypes from the media are one way people acquire knowledge regarding Black culture. According to Adams (2005), "Black students are seldom exposed to scholarly work related to the Black experience and must construct their young adult racial identities from the raw and flawed racial stereotypes perpetuated in the media and popular culture" (p. 285). In and outside the classroom, Black students have to combat negative stereotypes about their race and culture directly or indirectly. This can have a negative impact on their academic and personal success.

\section{Nigrescence}

William Cross developed Nigrescence theory in 1971, a theory considered the seminal Black racial identity development model (Vandiver, Cross, Worrell \& Fhagen-Smith, 2002). When Cross wrote about Nigrescence in 1971, he referred to it as "an identity change process as a Negro-to-Black conversion experience, the kind of process that could be seen in Black behavior during the Harlem Renaissance" (Cross, 1991, p. 189). Cross (1991) re-considered the theory as a resocializing experience, one that transforms a preexisting identity (e.g., non-Afrocentric identity) to one that is Afrocentric. Benjamin, Constantine, Richardson, and Wilson (2000) interpreted Nigrescence as the developmental process of becoming Black, an explanation of the Black identity and consciousness process for Black Americans. Evans, Forney, Guido, Patton, and Renn (2010) stated, "Cross introduced a five stage Nigrescence model, but in 1991 he condensed it to four stages" (p. 256) combining stages four and five. I reviewed the original five stages. Pre-encounter (stage 1) depicts the identity to be changed; Encounter (stage 2) isolates the point at which the person feels compelled to change; ImmersionEmersion (stage 3) describes the vortex of identity change; and Internalization and Internalization-Commitment (stages 4 and 5) describe the habituation and internalization of the new identity.

\section{Pre-Encounter Stage}

Persons in the pre-encounter stage hold attitudes that range from low salience to race neutrality to anti-Black (Cross, 1991). Little emphasis is given to race in 
this stage and people focus on other aspects of their lives including occupation, lifestyle, and religion as more salient. People do not acknowledge race as something that has affected their lives thus far. There are some Black people for whom being Black is very important, and there are some Black people who can hold an extreme attitude of anti-Blackness. Cross (1991) stated that "anti-Blacks loath other Blacks; they feel alienated from them and do not see Blacks or the Black community as potential or actual sources of personal support" (p. 191). Typically this stage occurs when someone does not realize that they have been raised with White westernized ideologies, because it is so embedded in their culture. Cross (1991) said that "persons have frequently been socialized to favor a Eurocentric cultural perspective" (p. 193).

\section{Encounter Stage}

People in the encounter stage must work around, slip through, or even shatter the relevance of their ideology and worldview. At the same time, others must provide some hint of direction in which to point the person to be resocialized or transformed (Cross, 1991). The encounter stage encompasses two steps, encounter and personalize. In the encounter step, an event happens that shapes how one views their race. Personalize occurs when an individual takes action as a result of the personal impact the event evoked on that person's world view. Cross (1991) pointed out that the encounter "need not to be negative" (p. 197) for the event to have impact and steer a person towards Nigrescence. What matters is that the encounter has a personally significant impact to be the catalyst to spur change in their thinking.

\section{Immersion-Emersion Stage}

The immersion-emersion stage of Nigrescence addresses the most sensational aspect of Black identity development, for it represents the vortex of psychological Nigrescence (Cross, 1991). It is during this stage that Black people will begin to shed their old worldview and construct a new frame of reference with the information they now have about race. The person has not yet changed, but commits to change. Cross (1991) said that "immersion is a strong powerful dominating sensation that is constantly energized by rage [at White people and culture], guilt [at having once been tricked into thinking Black ideas], and developing a sense of pride [in one's Black self, Black people, and Black culture]" (p. 203).

A sense of rage that is part of the immersion-emersion stage can be a catalyst for Black students to seek out history, art, and music that represent a culture they never knew existed. Cross (1991) stated that "a paradox conversion is that while rebelling against the larger society, the new convert may willingly conform to the demands for Black organizations" (p. 205). It is critical for PWIs to have safe 
spaces for Black students to feel comfortable in, as they navigate aspects of their identity that may be new to them. Harper and Quaye (2007) noted that many racial and ethnic minority students find themselves either subverting their identity to become involved in the mainstream culture or assimilating as they struggle to maintain a strong cultural connection to their racial identity. Connecting with others through a student organization or safe space can help aid in the support Black students may need to be successful in and outside of the classroom.

According to Vandiver et al., (2002), Black people can feel a variety of different emotions expressed in different ways.

If Blacks accepted being Black then, they were assumed to be psychologically healthy and to have a high self esteem. In contrast Blacks who accepted the values of White society were believed to suffer from self hatred and, as a result, low self-esteem. (p. 71)

Societal constructions disadvantage Black people through overt and covert forms of institutionalized racism. During the immersion stage, Black people decompress all the negative stereotypes associated with being Black, and view being Black through a different lens. Cross (1991) noted "emersion, an emergence from the emotionality and dead end, either/or, racist and oversimplified ideologies of the emergence experience (p. 207). During this time Black people are leveling off, which is facilitated by personal growth and the recognition that certain role models or heroes operate from a more advance state of identity development (Cross, 1991).

\section{Internalization Stage}

Internalization encompasses a transition period where one is working through the challenges and problems of a new identity (Cross, 1991). During this time people move away from how others view them to how they view themselves. Cross (1991) stated "the internalization marks the point of dissonance resolution and reconstruction of ones steady state personality and cognitive style" (p. 220). Black people begin to think critically about their new found racial identity and how it has shaped their life. As a result they embrace what it means to be Black and have Black self-love that they exude into the universe. Most importantly, "Black identity functions to fulfill the self protection, social anchorage, and bridging needs of the individual" (p. 220).

\section{Internalization-Commitment Stage}

Internalization-commitment focuses on the long-term interest of Black affairs over an extended amount of time (Cross, 1991). This stage is now combined with internalization. Cross (1991) explained that "consequently other than to repeat what has already been said about internalization a more differential look at internalization-commitment awaits the results of future research" (p. 220). 
According to Benjamin et al. (1998), Black identity development model helps "Blacks begin to shed a poor self worth and move toward embracing a positive Black self definition" (p. 96). This is the ultimate transformation, taking place when someone achieves a healthy racial identity. Racism, domination, and privilege are interwoven into society. As a result, "racism and race related stress may be experienced at the cultural, individual and institutional levels" (Johnson \& Arbona, 2006, p. 1). This can be experienced by Black people as well as other people with subordinate identities, which is why having a healthy racial identity is important for all students, no matter someone's race. According to Benjamin et al. (1998):

Healthy racial identity development is achieved when Blacks progress through a series of linear stages commencing with degrading thoughts and feelings about themselves and other Blacks accompanied by idealized beliefs about Whites, and ends with internalized positive feelings about themselves, other Blacks, and other racial groups. (p. 96)

\section{Conclusion}

Black identity development involves going through stages simultaneously. Black people begin with less awareness about their Black identity then progress to internalize positive thoughts, not only about themselves as a Black person, but about other racial groups as well. In addition, not only do people become aware of the historical ramifications about what it means to be Black, they also put thoughts and ideas into action to help educate and uplift the Black community.

Utilizing Cross's (1991) Nigrescence theory can help put into context the issues that can happen developmentally with a Black student regarding their racial identity in college. As institutions of higher education move towards attracting a more multicultural student population, student affairs professionals should be aware of the different stages of Black identity development. Competency in Nigrescence can serve as a reference for student affairs professionals and help assess the impact of Black students' relationships with their peers, faculty, and staff. Pope-Davis, Liu, Ledesma-Jones, and Nevitt (2000) stated that "identification with one's racial and cultural group represents a complex process" (p. 101) which does not happen overnight. It is a process that develops more as students interact with others from different backgrounds. 


\section{References}

Adams, T. A. (2005). Establishing intellectual space for Black students in predominantly White universities through Black studies. The Negro Educational Review, 56, 1-16.

Bakari, S. (1997). African American Racial Identity Development in Predominantly White Institutions: Challenges for Student Development Professionals. Different Perspectives on Majority Rules (1997). Paper 19.

Benjamin, E., Constantine, E., Richardson, T., Wilson, J. (1998). An overview of Black racial identity theories: Limitations and considerations for future theoretical conceptualizations. Applied and Preventive Psychology, 75, 95-99.

Cross, W. E. (1991). Shades of Black: Diversity in African-American identity. Philadelphia: Temple University Press.

Evans, N. J., Forney, D. S., Guido, F. M., Patton, L. D., \& Renn, K. A. (2010). Student development in college: Theory, research, and practice. San Francisco, CA: JosseyBass Publishers.

Harper, S. R., \& Quaye, S. J. (2007). Student Organizations as Venues for Black Identity Expression and Development among African American Male Student Leaders. Journal of College Student Development, 48(2), 127-144.

hooks, b. (1994). Teaching to transgress: Education as the practice of freedom. New York: Routledge.

Johnson, S. C., \& Arbona, C. (2006). The Relation of Ethnic Identity, Racial Identity, and Race-Related Stress among African American College Students. Journal of College Student Development, 47(5), 495-507.

Magolda, B. (2001). Making their own way: Narratives for transforming higher education to promote self-development. Sterling, VA: Stylus

Pope-Davis, D. B., Liu, W. M., Ledesma-Jones, S., \& Nevitt, J. (2000). African American Acculturation and Black Racial Identity: A Preliminary Investigation. Journal of Multicultural Counseling and Development, 28(2), 98-112.

Tatum, B. D. (1997). Why are all the Black kids sitting together in the cafeteria? And other conversations about race. New York, NY: Basic Books.

Vandiver, B. J., Cross, W. E., Jr., Worrell, F. C., \& Fhagen-Smith, P. E. (2002). Validating the Cross Racial Identity Scale. Journal of Counseling Psychology, 49(1), 71-85. doi:10.1037//0022-0167.49.1.71 